\title{
HUBUNGAN TINGKAT STRES DENGAN KINERJA PERAWAT DI POLIKLINIK RUMAH SAKIT Dr. OEN SOLO BARU
}

\author{
Oleh : \\ Tunjung Sri Yulianti ${ }^{1}$, Devina Setya Dewi ${ }^{2}$
}

\begin{abstract}
Background this study was in the lives of everyday people cannot escape from stress, such as when humans meet challenges, threat or when it should be trying to cope with the expectations of their environment. For those who are not ready would cause a gap between body and soul. Nurses are the health care personnel who are 24 hours near the patient. the workload incurred by nurses is quite high because nursing is a profession with a group of the most front and nearest to the suffering, pain, and misery experienced by the patient and his family. Nurse at the Polyclinic Dr. Oen Solo Baru hospital Recently had a flurry of work are high, many of the demands of the work to be completed, and are expected to serve the patient with the best possible. Stressful conditions in conjunction with the nurse performance had the meaning that is important, because with a high level of stressor then it will affect the process of nursing services to patients.
\end{abstract}

The purpose of this research is to know the stress level of relationship with the nurse performance at the Polyclinic Dr. Oen Solo Baru hospital.

The method of this research is correlation research of two variables, by involving the first variable is the stress of work and the second variable is the performance of nurses, with statistical test Fisher with $p$ value 0.05 .

The results from this study is there is no relationship between the level of stress with the nurse performance at the Polyclinic Dr. Oen Solo Baru hospital with the value of significancy 1,000 for 2 -sided and 0.455 for 1 -sided.

Conclusion of this research is that there is no relationship between the level of stress with the nurse performance at the Polyclinic Dr. Oen Solo Baru hospital.

Key words: Stress Levels, Performance.

\section{PENDAHULUAN}

Dalam kehidupan sehari-hari manusia tidak bisa lepas dari stres. Saat ini berbagai perubahan sosial maupun psikologis banyak terjadi. Menurut Selye (1950) sebagaimana dikutip oleh Hawari (2011), stres adalah reaksi dari tubuh (respons) yang sifatnya non spesifik terhadap setiap tuntutan beban atasnya. Misalnya ketika manusia menghadapi tantangantantangan (challenge), ketika dihadapkan pada ancaman (threat) atau ketika harus berusaha mengatasi harapanharapan yang tidak realistis dari lingkungannya. Hal ini bagi beberapa masyarakat yang tidak siap akan menimbulkan suatu kesenjangan antara jiwa dan raga. Perawat adalah tenaga kesehatan yang berada 24 jam didekat pasien. Beban kerja yang ditanggung oleh perawat cukup tinggi karena keperawatan merupakan kelompok profesi paling depan dan terdekat dengan penderitaan, kesakitan, serta kesengsaraan yang dialami pasien dan keluarganya. (Nursalam, 2011) Perawat di Poliklinik RS. Dr. Oen Solo Baru mempunyai kesibukan kerja yang tinggi, 
banyak tuntutan pekerjaan yang harus diselesaikan. Kondisi stres dalam hubungannya dengan kinerja perawat mempunyai arti yang penting, karena dengan tingkat stressor yang tinggi maka akan mempengaruhi proses pelayanan keperawatan kepada pasien.

\section{METODE PENELITIAN}

Penelitian ini merupakan penelitian korelasi dengan melibatkan dua variabel, variabel pertama adalah stres kerja dan variabel yang kedua adalah kinerja perawat. Subjek penelitian ini adalah perawat poliklinik RS Dr. Oen Solo Baru yang berjumlah 27 orang. Dalam penelitian ini peneliti menggunakan teknik sampling jenuh sehingga yang menjadi sampel adalah semua perawat di Poliklinik RS Dr. Oen Solo Baru.

\section{HASIL PENELITIAN}

Berdasarkan penelitian yang telah dilakukan didapatkan hasil sebagai berikut :

Tabel 1. Distribusi Frekuensi Tingkat Stres

\begin{tabular}{lcc}
\hline Tingkat Stres & $\mathbf{f}$ & $\%$ \\
\hline Ringan & 24 & 88,88 \\
\hline Sedang & 3 & 11,12 \\
\hline Berat & 0 & 0 \\
\hline Jumlah & 27 & 100 \\
\hline
\end{tabular}

Dari tabel di atas dapat diketahui bahwa sebagian besar responden berada pada tingkat stress yang ringan yaitu 24 orang $(88,88 \%), 3$ responden $(11,12 \%)$ berada pada tingkat stress sedang dan tidak ada responden yang berada pada tingkat stress yang berat.
Tabel 2. Distribusi Frekuensi Kinerja Perawat

\begin{tabular}{ccc}
\hline $\begin{array}{c}\text { Kinerja } \\
\text { Perawat }\end{array}$ & $\mathbf{f}$ & $\%$ \\
\hline Kurang & 0 & 0 \\
\hline Sedang & 21 & 77,8 \\
\hline Baik & 6 & 22,2 \\
\hline Jumlah & 27 & 100 \\
\hline
\end{tabular}

Dari tabel di atas dapat diketahui bahwa sebagian besar responden yaitu 21 perawat $(77,8 \%)$ mempunyai kinerja sedang dan 6 perawat $(22,2 \%)$ mempunyai kinerja baik.

Tabel 3. Hubungan Tingkat Stres Dengan Kinerja Perawat di Poliklinik RS Dr. Oen Solo Baru

\begin{tabular}{lcccc}
\hline \multirow{2}{*}{$\begin{array}{c}\text { Tingkat } \\
\text { Stres }\end{array}$} & \multicolumn{4}{c}{ Kinerja Perawat } \\
\cline { 2 - 5 } & Kurang & Sedang & Baik & Jml \\
\hline Ringan & 0 & 18 & 6 & 24 \\
\hline Sedang & 0 & 3 & 0 & 3 \\
\hline Berat & 0 & 0 & 0 & 0 \\
\hline Total & 0 & 21 & 6 & 27 \\
\hline
\end{tabular}

Dari uji statistik dengan uji Fisher diperoleh nilai significancy 1.000 untuk 2-sided dan 0.455 untuk 1 sided. Karena probabilitas > 0,05 sehingga $\mathrm{Ha}$ ditolak, yang berarti tidak ada hubungan antara tingkat stres dengan kinerja perawat Poliklinik RS Dr. Oen Solo Baru.

\section{PEMBAHASAN}

1. Tingkat Stres
Menurut
Patel
(1966)
sebagaimana dikutip oleh
Hawari (2011), mendefinisikan
stres sebagai reaksi tertentu yang muncul pada tubuh yang bisa disebabkan oleh berbagai tuntutan, misalnya ketika manusia menghadapi tantangan-tantangan (challenge), ketika dihadapkan pada ancaman (threat) atau ketika harus berusaha 
mengatasi harapan-harapan yang tidak realistis dari lingkungannya.

Menurut Hawari (2011), seseorang yang berada pada kondisi stres tahap I merupakan tahapan stres yang paling ringan, gejala yang dirasakan sebagai berikut :

a. Semangat bekerja besar, berlebihan (over acting).

b. Penglihatan "tajam" tidak sebagaimana biasanya.

c. Merasa mampu menyelesaikan pekerjaan lebih dari biasanya, namun tanpa disadari cadangan energi dihabiskan (all out) disertai rasa gugup yang berlebihan pula.

d. Merasa senang dengan pekerjaannya itu dan semakin bertambah semangat, namun tanpa disadari cadangan energi semakin menipis.

Memperhatikan definisi dan tahapan stress diatas, dikaitkan dengan rentang usia yang dimiliki responden, maka dapat diketahui bahwa responden penelitian ini sedang menghadapi tantangantantangan (challenge) dalam hidupnya baik itu yang berhubungan dengan pekerjaan dan karirnya maupun terkait dengan kehidupan pribadinya.

\section{Kinerja Perawat}

Menurut llyas (2002) sebagaimana dikutip oleh Hariyati (2014), kinerja adalah penampilan hasil karya personil baik kuantitas maupun kualitas dalam suatu organisasi. Sedangkan menurut Nursalam (2011), ada tiga jenis penilaian kinerja yaitu : penilaian kinerja secara individual atau self assessment, penilaian sesama sejawat atau peer assessment, dan penilaian dari atasan.

Pada responden penelitian ini, penilaian kinerja dilakukan oleh atasan dengan menggunakan alat evaluasi penampilan kerja dari Kemenkes (2013) dengan melihat kemampuan dan implementasi asuhan keperawatan, tanggung jawab dan pelaksanaan kepemimpinan, pengembangan profesi, kemampuan berorientasi kepada mutu, keselamatan pasien dan berorientasi pada pelanggan.

3. Hubungan Tingkat Stres

Dengan Kinerja Perawat

Menurut Videbeck (2008) dalam Nasir dan Muhith (2011), stress dapat menghasilkan berbagai respon. Salah satu respon stress adalah perubahan psikologis antara lain: ansietas, kepenatan, kelelahan mental, kehilangan motivasi, penurunan produktivitas dan kualitas kinerja pekerjaan, ketidakmampuan

berkonsentrasi terhadap tugas, kecenderungan untuk berbuat kesalahan, dan sebagainya.

Berdasarkan penghitungan statistik hasil penelitian pada responden ini menunjukkan bahwa tidak ada hubungan antara tingkat stres dan kinerja pada perawat poliklinik rumah sakit Dr. Oen Solo Baru. Data tingkat stres yang diperoleh dari responden menunjukkan bahwa sebagian besar responden mempunyai tingkat stres yang ringan. Dimana menurut Hawari (2011), seseorang yang mengalami stres ringan akan cenderung mempunyai semangat bekerja besar. Dari paparan tersebut dapat diketahui bahwa tingkat stress responden yang rata- 
rata berada pada tingkat yang ringan justru meningkatkan semangat responden dalam bekerja.

Pada responden penelitian ini diperoleh data bahwa 13 responden mendapatkan penambahan anggota keluarga dengan kelahiran anak dan 5 orang pindah rumah serta 23 orang menyatakan bahwa lingkungan kerjanya memungkinkan untuk berkembang.

Berdasarkan paparan teori sebelumnya dapat disimpulkan bahwa responden penelitian ini mengalami keadaan-keadaan yang bisa menjadi sumber stresnya. Tetapi mereka mencoba memenuhi tuntutan dari keadaan yang mereka alami agar mendapatkan sesuatu yang baik dan berharga, sehingga stres yang mereka alami berada pada tahap ringan dan termasuk stres yang baik atau eustres. Hal ini sesuai dengan paparan dari Nasir dan Muhith (2011), stres yang baik (eustres) terjadi jika setiap stimulus mempunyai arti sebagai hal yang memberikan pelajaran bagi kita. Dengan demikian, dikatakan stres positif apabila setiap kejadian dihadapi dengan selalu berpikiran positif dan setiap stimulus yang masuk merupakan suatu pelajaran yang berharga dan mendorong seseorang untuk selalu berpikir dan berperilaku bagaimana agar apa yang dilakukan selalu membawa manfaat dan bukan bencana.

Sedangkan data yang ditemukan pada responden pada variabel kinerja adalah rata-rata responden dinilai memiliki kinerja yang sedang. Menurut Gibson (1997) sebagaimana dikutip oleh
Nursalam (2014), ada 3 faktor yang berpengaruh terhadap kinerja, yaitu: faktor individu (kemampuan, ketrampilan, latar belakang keluarga, pengalaman kerja, tingkat sosial dan demografi seseorang), faktor psikologis (persepsi, peran, sikap, kepribadian, motivasi, dan kepuasan kerja) dan faktor organisasi (struktur organisasi, desain pekerjaan, kepemimpinan, sistem penghargaan/reward system). Pada faktor individu, sebagian besar responden (70,4\%) mempunyai tingkat sosial yang cukup dengan gaji rata-rata 2-5 juta/bulan, sedangkan dari faktor psikologi terkait kepuasan kerja, $88,88 \%$ responden menyatakan pekerjaan sekarang sesuai dengan harapannya dan jika dilihat dari faktor organisasi $85,19 \%$ responden menyatakan tempat kerjanya memungkinkan untuk berkembang.

Menurut Nasir dan Muhith (2011), kepuasan kerja dan kecocokan antara pegawai dengan atasan serta organisasi sangat berpengaruh pada kinerja. Mereka yang merasakan sedikit stres adalah mereka yang bekerja di lingkungan dimana mereka dapat berkembang dibandingkan mereka yang bekerja di lingkungan yang sulit untuk berkembang. Pada responden diperoleh informasi bahwa 26 responden $(96,29 \%)$ menyatakan beban kerja yang ada sesuai dengan kemampuan. Kondisi-kondisi diatas mampu mendukung kinerja responden sehingga diperoleh hasil kinerja dalam kategori sedang dan baik. 
Dengan demikian dapa
dipahami apabila hasi
penelitian ini menyatakan
bahwa tidak ada hubungan
antara tingkat stres dengan
kinerja perawat, karena
meskipun responden mengalami stres tetapi tingkat stres responden berada pada kategori ringan dimana stres yang ringan tersebut justru memacu individu untuk bertahan. Apalagi didukung dengan usia responden yang berada pada rentang dewasa muda dimana bekerja dan pengembangan karir menjadi tuntutan dan karakteristik utama. Sementara hal lain yang mendukung adalah pekerjaan saat ini sesuai dengan yang harapan, lingkungan kerja responden memungkinkan untuk berkembang dan beban kerja yang diterima responden sesuai dengan kemampuannya.

Penelitian ini berbeda dengan penelitian sebelumnya yang dilakukan oleh Widjenegara, Damayanti, Harini (2011) dan Kartika (2009). Kedua penelitian tersebut mengamati variabel stress kerja sehingga yang diamati khusus hal-hal terkait dengan pekerjaan yang bisa menimbulkan stres dan bisa mempengaruhi kinerja. Sementara penelitian yang dilakukan oleh peneliti mengamati semua faktor yang memungkinkan untuk menimbulkan stres yang bisa berdampak pada kinerja perawat. Demikian juga dengan hasil penelitian ini berbeda dengan penelitian sebelumnya. Jika pada penelitian terdahulu diperoleh hasil bahwa stres kerja berhubungan dan berpengaruh secara signifikan pada kinerja sementara pada penelitian ini dari penghitungan statistik diperoleh hasil tidak ada hubungan antara tingkat stres dan kinerja perawat.

\section{KESIMPULAN}

1. Data penelitian menunjukkan sebagian besar responden yaitu 24 orang (88,88\%) berada pada tingkat stres yang ringan, 3 responden $(11,12 \%)$ berada pada tingkat stres sedang dan tidak ada responden yang berada pada tingkat stres yang berat.

2. Sebagian besar responden yaitu 21 perawat $(77,8 \%)$ mempunyai kinerja sedang dan 6 perawat $(22,2 \%)$ mempunyai kinerja baik.

3. Hasil analisa bivariat dengan uji Fisher diperoleh nilai significancy 1.000 untuk 2sided dan 0.455 untuk 1-sided, sehingga $\mathrm{Ha}$ ditolak, yang berarti tidak ada hubungan antara tingkat stres dengan kinerja perawat poliklinik RS Dr. Oen Solo Baru.

\section{SARAN}

1. Bagi Perawat Poliklinik

Meningkatkan kinerja dengan meminimalkan stres dan mengoptimalkan faktor-faktor pendukung yang sudah dimiliki, baik itu dari individu, keluarga maupun lingkungan kerja.

2. Bagi Rumah Sakit

a. Menyusun program-program untuk meningkatkan kinerja, karena dari data penelitian kinerja perawat sebagian besar masih pada kategori sedang dan baru 22,2\% perawat poliklinik yang mempunyai kinerja baik.

b. Menyusun instrumen evaluasi kinerja perawat secara baku berdasarkan kompetensi perawat poliklinik dan disesuaikan dengan standar kinerja 
yang ditetapkan oleh rumah sakit.

c. Melakukan evaluasi kinerja secara berkala dan melakukan follow up yang diperlukan berdasarkan hasil evaluasi.

3. Bagi Peneliti Selanjutnya Melakukan penelitian lanjutan terkait dengan variabel yang lebih spesifik yaitu stress kerja yang dikaitkan dengan kinerja.

\section{DAFTAR PUSTAKA}

Cherie, Amsale dan Ato Berhane Gebrekidan. Kepemimpinan dan Manajemen Keperawatan. Yogyakarta: Imperium, 2013.

Hariyati, Tutik Sri. Perencanaan, Pengembangan dan Utilisasi Tenaga Keperawatan. Jakarta: Rajawali Pers, 2014.

Hidayat, A. Aziz Alimul. Metode Penelitian Keperawatan dan Teknik Analisis Data. Jakarta: Salemba Medika, 2007.

. Riset Keperawatan dan Teknik penulisan ilmiah, Edisi 2. Jakarta: Salemba Medika, 2008.

Hawari, Dadang. Manajemen Stres Cemas dan Depresi. Jakarta: Balai Penerbitan FKUI, 2011.

Nasir, Abdul dan Abdul Muhith. Dasar- Dasar Keperawatan Jiwa: Pengantar dan Teori. Jakarta: Salemba Medika, 2011.
Nursalam. Manajemen Keperawatan: Aplikasi dalam Praktik Keperawatan Profesional. Edisi 3. Jakarta: Salemba Medika, 2011.

Manajemen Keperawatan: Aplikasi dalam Praktik Keperawatan Profesional. Edisi 4. Jakarta: Salemba Medika, 2014.

Simamora, Roymond H. Buku Ajar Manajemen Keperawatan. Jakarta: EGC, 2012.

Widjenegara, Damayanti, dan Harini. " Stres Kerja dengan Kinerja Perawat". Diunduh pada 24 November 2014.

Kartika, Wahyu. "Pengaruh Stres Kerja dengan Kinerja Perawat di Rumah Sakit Jiwa". Diunduh tanggal 28 November 2014.

\footnotetext{
1 Dosen AKPER Panti Kosala Surakarta

2 Mahasiswa AKPER Panti Kosala Surakarta
} 